\title{
W POSZUKIWANIU NOWEGO PARADYGMATU: TEOLOGIA SPOTKANIA JAKO NOWY SPOSÓB UPRAWIANIA REFLEKSJI NAD OBJAWIENIEM
}

DOI: http://dx.doi.org/10.12775/TiCz.2017.050

\section{ZADANIA TEOLOGIl}

Teologia, jako systematyczna dyscyplina wiedzy, w swojej refleksji pochyla się nad analizą danych z Objawienia. W katolickiej hermeneutyce źródłem tegoż Objawienia jest sam Bóg, który manifestuje się człowiekowi na kartach Pisma Świętego oraz w nurcie Tradycji Konstytutywnej. Jednym z naczelnych celów teologii jest bez wątpienia konsekwentne dążenie do doskonalszego rozumienia prawd objawionych, a także ich systematyczna analiza oparta na właściwej sobie metodzie. Trzeba zauważyć, że teologia nie powinna pozostawać jedynie w sferze theoría. Winna ona rzutować także na praxis wspólnoty religijnej oraz inspirować każdego konkretnego człowieka do zajmowania określonych postaw. Aby

* Artur Kołodziejczyk - filozof, teolog. Doktorant z filozofii na Wydziale Filozoficzno-Historycznym Uniwersytetu Łódzkiego; absolwent teologii w Uniwersytecie Kardynała Stefana Wyszyńskiego w Warszawie. Jest członkiem Collegium Invisibile (kolodziejczykarthur@gmail.com). 
zaistniało to powiązanie, konieczne jest wyłonienie określonego paradygmatu, w oparciu na którym uprawia się teologię. Na przestrzeni dziejów można wskazać ich dość wiele, dla przykładu: parenetyczny, eksplikacyjny, apologetyczny czy tomistyczny. Obranie konkretnego paradygmatu daje początek pewnemu sposobowi uprawiania refleksji nad Objawieniem, a tym samym - konkretnej teologii. Pluralizm tych ujęć nie powinien dziwić. Na potrzebę takiego stanu rzeczy wskazuje także Międzynarodowa Komisja Teologiczna: „Pełnia i bogactwo (...) Objawienia są zbyt wielkie, aby mogły być ujęte przez jedną teologię, a ponieważ są podejmowane przez ludzi na różne sposoby, dają początek rozlicznym teologiom”'.

Bez wątpienia II Sobór Watykański stał się w historii Kościoła bardzo istotnym wydarzeniem. Zadanie stojące przed zgromadzonymi na Soborze da się streścić pod hasłem próby poszukiwania nowego sposobu uczestnictwa Kościoła w świecie oraz zdiagnozowania kondycji człowieka i świata we współczesności. Refleksje soborowe potoczyły się w dużym stopniu w pryzmacie humanizmu teocentrycznego ${ }^{2}$. W konsekwencji zaproponowano nowy sposób patrzenia na świat, na Kościół, na Objawienie, a także na Boga. Nowość spojrzenia ostatniego Soboru da się streścić pod hasłem przełomu antropologicznego ${ }^{3}$. W komentarzu do Konstytucji Gaudium et spes Jan Kracik napisał, że „Aby orędzie zbawienia nie zawisło w próżni, trzeba było starać się o powiązanie przekazu chrześcijańskiego ze samoświadomością człowieka, ze zrozumieniem, które on sam ma o sobie, oraz dopomagać mu w zrozumieniu swoich błędów jak i w odnajdywaniu siebie"4. Dwa słowa dobrze charakteryzują odtąd paradygmat Kościoła po II Soborze Watykańskim: uczestnictwo i posłanie. Punktem wyjścia dla uprawiania teologicznej refleksji uczyniono człowieka w jego konkretnej jakości i w jego relacji z Bogiem. Dzięki temu momentem konstytutywnym dla refleksji stało się konkretne doświadczenie.

${ }^{1}$ Międzynarodowa Komisja Teologiczna, Teologia dzisiaj: perspektywy, zasady i kryteria, Kraków 2012, s. 5.

2 Sobór Watykański II, konst. Gaudium et spes [dalej: GS], 3.

3 Zob. K. Rahner, Teologia a antropologia, tłum. A. Kłoczowski, „Znak” 21 (1969)12, s. 1538-1539.

4 J. Kracik, Komentarz do "Gaudium et spes», w: Sobór Watykański, konst. Gaudium et spes, Wrocław 2005, s. 211. 
Udzielenie mandatu misyjnego przez Jezusa Chrystusa wspólnocie eklezjalnej nasuwa szereg pytań o metodę aplikacji, o praxis. II Sobór Watykański wskazuje na konieczność odczytywania znaków czasu: „Kościół zawsze ma obowiązek badać znaki czasów i wyjaśniać je w świetle Ewangelii, tak aby mógł w sposób dostosowany do mentalności każdego pokolenia odpowiadać ludziom na ich odwieczne pytania dotyczące sensu życia obecnego i przyszłego oraz wzajemnego ich stosunku do siebie. Należy zatem poznawać i rozumieć świat, w którym żyjemy, a także jego dramatyczne nieraz oczekiwania, dążenia i właściwości” ${ }^{5}$. Kolejne pytanie, które przychodzi na myśl, dotyczy współcześnie niezbędnej metody. W jaki sposób należy dzisiaj realizować mandat misyjny i w jaki sposób uprawiać teologiczną refleksję?

Znany polski reporter, Ryszard Kapuściński, często mierzył się z pytaniem o palące problemy współczesnego świata. Pewne jego spostrzeżenie zasługuje na szczególną uwagę: „(...) istota [globalnej - przyp. aut.] wioski polega na tym, że jej mieszkańcy znają się blisko, obcują ze sobą, dzielą wspólny los. Tymczasem niczego takiego nie można powiedzieć o społeczeństwie naszej planety, które raczej przypomina anonimowy tłum na jednym $z$ wielkich lotnisk, tłum pędzących w pośpiechu, wzajemnie obojętnych i nieznających się ludzi”. Diagnoza „cesarza reportażu” na temat współczesności jest jasna. Streszcza się ona pod hasłem kryzysu wydarzenia spotkania z Innym oraz, w konsekwencji, w kryzysie dialogu interpersonalnego. R. Kapuściński nosił przekonanie o niezaprzeczalnej doniosłości spotkania z Innym, ale również o enigmatyczności i złożoności owego wydarzenia. Dlaczego to stwierdzenie miałoby być istotne w poszukiwaniu odpowiedzi na postawione pytanie o współczesną metodę teologiczną? W ramach odpowiedzi należy zacytować fragment pierwszej encykliki Benedykta XVI: „U początku bycia chrześcijaninem nie ma jakiejś wielkiej idei, ale natomiast spotkanie z wydarzeniem, z Osobą, która nadaje życiu nową perspektywę, a tym samym decydujące ukierunkowanie"?.

\footnotetext{
${ }^{5}$ GS, 4.

${ }^{6}$ R. Kapuściński, Ten Inny, Kraków 2007, s. 61.

7 Benedykt XVI, enc. Deus caritas est, 1.
} 
Spotkanie jest kluczowym faktem chrześcijaństwa. Przede wszystkim należy jednak pamiętać o tym podstawowym spotkaniu - człowieczeństwa z Boskością - które zaszło podczas Wcielenia. Fakt Jezusa Chrystusa jest zatem najdoskonalszym spotkaniem Boga z człowiekiem. W wymiarze antropologii filozoficzno-teologicznej stanowi ono archetypiczne wydarzenie spotkania. Ponadto, na co wskazuje papież Ratzinger, spotkanie jest zasadniczym momentem chrześcijaństwa. Nosi ono wręcz rangę wydarzenia. $Z$ tej przyczyny uwaga teologii winna być poświęcona szczególnie temu fenomenowi.

Mając na względzie postawione powyżej zapytanie trzeba przejść do tezy tej rozprawy. Za oś uprawiania współczesnej myśli teologicznej powinien zostać obrany paradygmat spotkaniowy. Oznacza to wysunięcie postulatu teologii spotkania jako nowego paradygmatu refleksji nad Bożym Objawieniem. Postulat, powiązany z tezą tej pracy, wiąże się również z koniecznością poszukiwania adekwatnej metody teologicznej $\mathrm{z}$ tak zorientowanym paradygmatem. Celem tego opracowania z zakresu antropologii filozoficzno-teologicznej będzie wykazanie możliwości uprawiania teologii spotkania jako nowego imperatywu teologicznego.

\section{KATEGORIA DOŚWIADCZENIA RELIGIJNEGO ORAZ SPOTKANIA}

Jak dotąd zostało wskazane, iż wieloaspektowość Objawienia Bożego jest źródłem dla przeróżnych paradygmatów uprawiania teologii chrześcijańskiej. Pluralizm teologicznych ujęć nie jest niczym niepokojącym. Co więcej, według wskazań Międzynarodowej Komisji Teologicznej wielość ta jest czymś naturalnym i pożądanym. Wspomniano także, że Kościół realizujący swój mandat misyjny musi być wrażliwy na znaki czasu. Odczytywanie ich jest swego rodzaju obowiązkiem, aby treść Objawienia skutecznie przenikała do rzeczywistości. Trzeba przypomnieć, że wcześniej postawiono jednak pytanie o teologiczny paradygmat, który byłby pożądany w czasach współczesnych. Mając na względzie świadomość, iż kluczowy fakt chrześcijaństwa, jakim jest Wcielenie Jezusa Chrystusa, stanowi spotkanie Boskości z człowieczeństwem, a także mając w pamięci to, że u początku chrześcijaństwa znajduje się spotkanie z Osobą ${ }^{8}$, trzeba uznać,

${ }^{8}$ Zob. Benedykt XVI, enc. Deus caritas est, 1. 
iż za współczesny paradygmat teologiczny winien zostać obrany czynnik spotkaniowy. Jeżeli fenomen wydarzenia spotkania jest zasadniczym elementem chrześcijaństwa i jeśli współcześnie - idąc choćby za diagnozą R. Kapuścińskiego - ludziom współczesnym przychodzi konfrontować się z kryzysem tegoż wydarzenia, to tym bardziej należy skoncentrować się na tym konstytutywnym elemencie. Jest $\mathrm{z}$ nim istotnie powiązana kategoria doświadczenia religijnego. Tym samym w niniejszym paragrafie zostanie wskazane, w sposób syntetyczny, na czym miałaby polegać istota teologii spotkania. Nie będzie można również nie wspomnieć o sposobie rozumienia doświadczenia religijnego.

Zanim zostanie przedstawiony sposób rozumienia teologii spotkania, znaczenia Wcielenia oraz samej kategorii doświadczenia religijnego, trzeba także pochylić się nad pytaniem o metodę. Otóż na jakiej metodzie opiera się postulat teologii spotkania? Warto powołać się na rozumienie metody teologicznej według Bernarda J. F. Lonergana, według którego owa metoda

(...) nie jest zbiorem reguł, które należy ślepo i drobiazgowo przestrzegać. Stanowi raczej ramy dla zespołowej twórczości. Określa różne rodzaje czynności, które mają wykonywać teologowie realizując różne zadania. Współczesna metoda ujmuje te zadania w kontekście nowożytnej nauki, nowożytnej humanistyki, nowożytnej filozofii, historyczności, wspólnej praktyki i współodpowiedzialności 9 .

Metoda jest więc czymś fundamentalnym w uprawianiu konkretnej dyscypliny wiedzy. Wytycza bowiem określone cele, właściwe specyfice danej dyscypliny, w odniesieniu do aktualnie panujących standardów oraz tendencji. II Sobór Watykański w Konstytucji Gaudium et spes zachęca do aplikowania metody indukcyjnej przy uprawianiu teologii. Polega ona na tym, aby za punkt wyjścia w refleksji teologicznej obrać konkretną rzeczywistość dziejową z jej całym zróżnicowaniem, w jej aktualnej problematyce. Dochodzenie do chrześcijańskiego rozwiązania konkretnych kwestii, w pryzmacie Revelatio Dei, miałoby przebiegać w teologii poprzez takie analizy, których początkiem byłoby uważne badanie konkretnej rzeczywistości dziejowej. W tym miejscu należałoby wskazać na kohe-

9 B. J. F. Lonergan, Metoda $w$ teologii, Warszawa 1976, s. 9. 
rentność tej metody z zachętą do badania znaków czasu, które miałoby być kluczowe $\mathrm{w}$ teologicznym praxis.

Trzeba jednak powrócić do kategorii wydarzenia spotkania w kontekście Wcielenia. Dlaczego kategoria wydarzenia spotkania miałaby być w chrześcijaństwie kluczowa? Na samym początku trzeba zauważyć, ze $\mathrm{w}$ teologii jest ona istotnie powiązana $\mathrm{z}$ faktem inkarnacji Jezusa Chrystusa. Wcielenie jest w teologii chrześcijańskiej podstawowym faktem, wręcz konstytuującym całe chrześcijaństwo. Dobrze oddaje to pierwszy rozdział

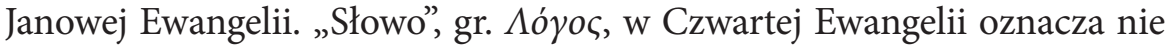
tylko Boga w relacji do samego siebie, drugą Osobę Trójjedynego Boga, ale także Boga wcielonego. W Jezusie Chrystusie zaszła unia hipostatyczna dwóch natur, Boskiej i ludzkiej, w jednej osobie (por. Flp 2,6-11) ${ }^{10}$. Między innymi już w tym aspekcie można mówić o spotkaniu Boskości z człowieczeństwem w jednej osobie Syna Bożego, czyli Jezusa z Nazaretu. Luigi Giussani zauważył, że „Fakt Wcielenia (...) pozostał w historii zasadniczo w swoim całokształcie: to Człowiek, który jest Bogiem, a zatem zna człowieka, i którego człowiek powinien naśladować, aby posiąść prawdziwe poznanie siebie samego i wszystkich rzeczy. (...) Chrześcijaństwo jest wydarzeniem"11. Wydarzenie Wcielenia (zob. J 1,1-5.10-14.16-18) stanowi dla chrześcijaństwa archetypiczne wydarzenie spotkania. Jest ono pierwszym - w perspektywie teologicznej - wydarzeniem, które stało się zaczynem Nowego Przymierza, umożliwiającym rozpoczęcie zbawienia. Wcielenie jest archetypicznym wydarzeniem spotkania w wymiarze makro - zcałym rodzajem ludzkim ${ }^{12}$, oraz $\mathrm{w}$ wymiarze mikro - z konkretnym człowiekiem.

${ }^{10} \mathrm{~W}$ tym sensie można mówić o perychorezie chrystologicznej.

11 L. Giussani, Chrześcijaństwo jako wyzwanie, tłum. D. Chodyniecki, Poznań 2002, s. 170-171.

12 Wymiar makro archetypicznego wydarzenia spotkania urzeczywistnia się w Objawieniu powszechnym, którego pełnią jest fakt Jezusa Chrystusa. Jest to nie tylko fakt teologiczny, ale również i historyczny, czyli intersubiektywnie weryfikowalny. Archetypiczne wydarzenie spotkania zrealizowało się zatem w wymiarze makro w historii, lecz jest również - z teologicznego punktu widzenia - współcześnie doświadczane w rzeczywistości sakramentalno-liturgicznej, czyli w publicznym kulcie Ludu Bożego. Liturgia stanowi bowiem przestrzeń dla spotkania $\mathrm{z}$ wcielonym i zmartwychwstałym Chrystusem w sakramentach. 
Wreszcie należy poświęcić uwagę kategorii doświadczenia religijnego. Niewątpliwymi elementami tegoż fenomenu jest podmiot roz-poznający (posługując się figurami retorycznymi filozofii spotkania, należałoby mówić o roz-poznającym „Ja”) oraz manifestująca się treść, czyli Bóg w swoim Objawieniu. Andrzej Perzyński zauważa, iż fenomen doświadczenia „(...) oznacza bezpośrednie uchwycenie przez świadomość jakiejś realności”"13. Jednakże co miałoby być ową „realnością” w sensie teologicznym? Byłyby to konkretne przeżycia - natury religijnej - osoby ludzkiej, będące formą uważnej percepcji treści manifestującej się transcendencji, w języku filozofii spotkania - Wiecznego Ty ${ }^{14}$. Jeżeli podmiotem doświadczenia religijnego jest konkretnie przeżywana realność-transcendencja, to doświadczenie religijne jest $\mathrm{w}$ istocie powiązane $\mathrm{z}$ kategorią przeżycia istnienia konkretnej Obecności. To zaś prowadzi w rezultacie do wydarzenia spotkania (nadal w strumieniu uważnie przeżywanego doświadczenia), aby wreszcie sfinalizować się w wydarzeniu zjednoczenia w relacji wiary (na bazie wolnej i rozumnej decyzji osoby ludzkiej). Doświadczanie i przeżywanie faktu objawiającego się Absolutu, a więc w rezultacie spotkanie z Nim, prowadzi do świadomego rozpoznania Jego realnej obecności. Doniosłość tego wydarzenia wiąże się również z rozpoznaniem radykalnej inności manifestującej się Tajemnicy. Ta radykalna inność jest z kolei postrzegana jako zasadnicza różnica ontyczna. Świadomość człowieka o inności Tajemnicy narasta proporcjonalnie do ciągłości przeżywania tego objawiania się. A. Perzyński stawia wniosek, że „W pewnym momencie człowiek spostrzega, że to nie on spotyka Boga, ale że jest spotkany przez Boga. Jest to krok

13 A. Perzyński, Metoda teologiczna, Warszawa 2006, s. 148.

${ }_{14}$ Polski teolog Henryk Seweryniak zauważa, że dostrzeganie wymiaru transcendencji jest możliwe ze względu na fakt posiadania przez człowieka tzw. zdolności autotranscendencji. H. Seweryniak wylicza osiem takich dyspozycji: [1] pragnienie bycia, szczęścia i prawdy; [2] pragnienie sensu (głębsze badania w tym zakresie przeprowadził Victor E. Frankl); [3] zadziwienie cudem istnienia; [4] doświadczenie basic trust (Eric Ericson dokonał kompleksowej analizy tegoż uzdolnienia); [5] zdolność do tworzenia kultury; [6] fenomen sumienia; [7] głębia miłości; [8] ukierunkowanie źródłowe (zob. H. Seweryniak, Teologia fundamentalna, Warszawa 2010, s. 105-116). Podobnie orzeka Konstytucja Dei Filius I Soboru Watykańskiego: „Święta Matka Kościół utrzymuje i naucza, że naturalnym światłem rozumu ludzkiego można z rzeczy stworzonych w sposób pewny poznać Boga, początek i cel wszystkich rzeczy” (por. Katechizm Kościoła Katolickiego, 50). 
$\mathrm{w}$ nowe doświadczenie wiary, doświadczenie spotkania z wydarzeniem chrześcijańskim"15. Doświadczenie religijne polega więc na uważnym przeżywaniu przez konkretną jednostkę danej naoczności, którą stanowi objawiający się Wieczny Ty. Owo realne doświadczenie jest zatem sceną dla urzeczywistnienia się wydarzenia spotkania Ja z Wiecznym Ty, które $\mathrm{w}$ rezultacie jest zdolne wytworzyć więź wiary. Warunkiem jest jeszcze, jak wspomniano wcześniej, afirmacja manifestującej się Tajemnicy. W ten sposób akt wiary jest poprzedzony realnym doświadczeniem Obecności i wydarzenia spotkania. Dynamikę owego spotkania człowieka z Bogiem - w strumieniu przeżywanego doświadczenia religijnego - wyraża dialog. Transcendencja, rozumiana w tym teologicznym sensie jako Bóg, inicjuje dialog ${ }^{16} \mathrm{z}$ człowiekiem poprzez - używając języka Martina Bubera - zagadnięcie. Polegałoby ono na zaprezentowaniu własnego istnienia w akcie doświadczenia religijnego konkretnego Ja. W rezultacie wytwarza się tzw. napięcie dialogiczne. Podmiot spotykający odczuwa potrzebę odpowiedzi, zajęcia pewnego stanowiska. Odpowiedź ta przyjmuje postać decyzji nawiązania więzi z objawiającym się Bogiem lub decyzji zaniechania tego. Należy w tym miejscu zacytować słowa Hansa U. von Balthasara, według którego „(...) wiara jest spotkaniem całego człowieka z Bogiem”"17.

Należy postawić pytanie o konsekwencje wydarzenia spotkania z Tajemnicą. W doświadczeniu religijnym człowiek spotyka się z realnością Boga, rozpoznając przy okazji swoje własne istnienie na tle innych jestestw. Uprzytamnia sobie również swoją niewspółmierność względem innych bytów i zaczyna zdawać sobie sprawę z faktu, że jedynie Tajemnica jest jego właściwym naprzeciw. $Z$ tej racji można twierdzić, że osoba ludz-

15 A. Perzyński, Metoda, s. 148-149.

${ }^{16}$ Oddzielnym problemem zarówno filozoficznym, jak i teologicznym jest pytanie o to, kto inicjuje ów dialog. Trzeba mieć świadomość, że ten problem jest poruszany w refleksji teologicznej, jednakże nie stanowi istoty niniejszego przedłożenia. Autor przyjmuje stanowisko, iż odpowiedź człowieka na wszelki akt zagadnięcia przez Wieczne Ty ma charakter responsoryczny - inicjatywa wychodzi od strony objawiającego się Boga, przeżywanego przez „Ja” roz-poznające w dynamice doświadczenia religijnego. Trudno również wskazać na jednoznaczne warunki, w których Bóg zagaduje człowieka. Fenomenologiczna analiza doświadczeń religijnych pokazuje, że moment ten ma szczególnie zindywidualizowany charakter. Jednakże z pewnością można doszukiwać się pewnych podobieństw, nie zaś identyczności.

${ }^{17}$ H. U. von Balthasar, Gloria, t. 1, Mediolan 1975, s. 203. 
ka jest podmiotem transcendującym rzeczywistość. M. Buber stwierdził w związku z tym, że „(...) człowiek z momentu najwyższego spotkania nie wychodzi taki sam, jak weń wszed»"18. Spotkanie z Bogiem w doświadczeniu religijnym wymaga od człowieka zajęcia określonego stanowiska w sprawie zawiązania więzi relacji wiary lub zaniechania tego aktu.

\section{PODSUMOWANIE}

Podsumowując, należy zapytać, co zatem miałoby być przedmiotem teologii spotkania? Udzielając syntetycznej odpowiedzi, trzeba zauważyć, że przedmiotem teologii spotkania jest konkretne doświadczenie religijne, wpisane w wydarzenie spotkania osoby ludzkiej z realnie manifestującym się Wiecznym Ty. Zadaniem teologii spotkania winno być także analizowanie konsekwencji i struktury wydarzenia spotkania Ja z Wiecznym Ty. Wydarzenie to jest - w tej perspektywie - zasadniczym dla człowieka momentem, zdolnym do otwarcia relacji wiary. Sam akt wiary jest w takim rozumieniu postrzegany jako rozumna, wolna i świadoma odpowiedź człowieka, przybierająca postać decyzji. Metoda teologii spotkania jest indukcyjna. Puntem wyjścia jest w tym kontekście przeżywanie rzeczywistości oraz konkretnego faktu o naturze religijnej przez „Ja” roz-poznające, a w wyniku tego - wyciąganie wniosków z analiz z tego momentu i ich systematyzacja.

Nie można nie wspomnieć o licznych perspektywach badawczych, które otwierają się przed tak zorientowanym teologicznym paradygmatem. Teologia o paradygmacie spotkaniowym może być interesującym narzędziem do rekonstrukcji i zbadania doświadczenia religijnego u wielu osób. Ponadto mogłaby w interesujący sposób zostać zestawiona z badaniami interdyscyplinarnymi z pogranicza teologii i psychologii, teologii i socjologii czy teologii i filozofii (zwłaszcza filozofii dialogu). Analiza elementu doświadczenia religijnego w opisach spotkań konkretnych postaci z Bogiem mogłaby także stać się okazją do poczynienia ważnych analiz i postawienia interesujących wniosków w nurcie biblistyki.

${ }^{18}$ M. Buber, Ja i Ty: wybór pism filozoficznych, tłum. J. Doktór, Warszawa 1992, s. 108. 
Kwestie wiary oraz ludzkiego doświadczenia były na przestrzeni dziejów rozpatrywane z wielu stron. Dzisiaj „(...) obecne jest przeświadczenie, że dzisiaj wielu ludzi tęskni za wiarą, która by była również sprawą doświadczenia. Nie wystarcza im wiara jako «nauka z zewnątrz», informacja «od góry», poszukują natomiast wiary, która by się łączyła z ich sytuacją życiową oraz doświadczeniami życia, z sytuacją świata, w którym żyją. Stąd pojawia się pytanie o relację między wiarą i doświadczeniem, pytanie o możliwość budowania «teologii doświadczenia»" 19 . Nie ulega wątpliwości, że teologia powinna temu wyzwaniu sprostać, jedną z odpowiedzi jest zaś zaprezentowana w niniejszym opracowaniu szkicowa propozycja teologii spotkania.

Streszczenie. Współczesny świat, podlegający nieustannym przemianom, stawia przed teologią nowe wyzwania. Jednym z nich jest aktualizacja treści Objawienia Bożego, aby stały się one zrozumiałe i lepiej trafiały do konkretnego człowieka. Wiąże się to $\mathrm{w}$ istotny sposób $\mathrm{z}$ koniecznością zdiagnozowania kondycji człowieka w danym okresie dziejowym. Autor argumentuje, że współcześnie trzeba konfrontować się z kryzysem wydarzenia spotkania i dialogu interpersonalnego. Wskazuje także, że są to jedne z elementarnych czynników Objawienia chrześcijańskiego. Tym samym postuluje, aby we współczesnej teologii posługiwać się paradygmatem spotkaniowym. Teologia spotkania winna analizować doświadczenie religijne człowieka, w którym człowiek uważnie przeżywa manifestujący się Absolut oraz konsekwencje wynikające z tegoż doświadczenia dla osoby ludzkiej. Wskazuje także, iż zagadnienie spotkania jest dla chrześcijaństwa kluczowe, albowiem we Wcieleniu doszło do wydarzenia spotkania Boskości z człowieczeństwem. W zakończeniu pracy wskazuje na perspektywy badawcze - także z zakresu analiz interdyscyplinarnych - dla teologii spotkania.

Słowa kluczowe: teologia spotkania; dialog; spotkanie; człowiek; paradygmat teologiczny.

Abstract. The Search for a New Paradigm: Theology of the Encounter as a New Way of Reflection on Revelation. This paper argues that today the current question - one of the most important in theology - is: which theological paradigm should be applied today? We have to remember that this question is not groundless. According to the International Theological Commission, the sheer fulness and richness of Revelation is too great to be grasped by any one theology. In fact gives rise to multiple theologies as it is received in diverse ways by human beings. The author argues that in contemporary theology should appear paradigm of encounter. Theology of the encounter should exa-

19 A. Perzyński, Metoda, s. 159. 
mine the religious experience of human being. In this experience, happens the encounter between God and man. God initiates the dialogue.

Key words: theology of the encounter; dialogue; encounter; human being; paradigm of encounter.

\section{BIBLIOGRAFIA}

Balthasar H. U. von, Gloria, t. 1, Mediolan 1975.

Benedykt XVI, Adhortacja Verbum domini.

Benedykt XVI, Encyklika Deus caritas est.

Buber M., Ja i Ty: wybór pism filozoficznych, tłum. J. Doktór, Warszawa 1992.

Giussani L., Chrześcijaństwo jako wyzwanie, tłum. D. Chodyniecki, Poznań 2002.

II Sobór Watykański, Konstytucja Gaudium et spes.

Kapuściński R., Ten Inny, Kraków 2007.

Kracik, J., Komentarz do „Gaudium et spes”, w: Sobór Watykański, Konstytucja Gaudium et spes, Wrocław 2005.

Lonergan B. J. F., Metoda $w$ teologii, Warszawa 1976.

Międzynarodowa Komisja Teologiczna, Teologia dzisiaj: perspektywy, zasady i kryteria, Kraków 2012.

Perzyński A., Metoda teologiczna, Warszawa 2006.

Seweryniak H., Teologia fundamentalna, Warszawa 2010.

Balthasar H. U., Gloria, t. 1, Mediolan 1975. 